\title{
Sensitive Magnetic Field Sensor Based on Compensated Double Pick Up Coil
}

\author{
Budi Purnama, Suharyana, and Artono Dwijo Sutomo ${ }^{1}$
}

\begin{abstract}
Sensitive magnetic field sensor based on compensated double pick up coil has been developed. In order to confirm sensitifity of modified design, experiment carried out in two steps. Firstly, sensitify of conventional design is clarified. Here pick up coil as an active sensor and solenoid as an exitation coil is separately made. Secondly, modified sensor of integrated configuration is developed. Here for both active flux gate sensor and the exitation coil is made in same one core magnetic. Ferrite and standar foil soft magnetic is utilized in this experiment. In attention, frequency of $50 \mathrm{~Hz}$ is used for the whole experimens. A result showed that sensitvity of the integrated configuration sensor is much larger than conventional one. Then, power consume of the integrated flux gate sensor is much lower than conventional. Finally, a range measurement of the integrated configuration sensor can be realized less than $20 \mu \mathrm{T}$ which potential may perhaps sense a change of natural local magnetic field.
\end{abstract}

Keywords—double pick up coil, hysteresis curve, magnetic field

Abstrak-Sensor medan magnet sensitif berbasis double pick up coil terkompensasi telah dikembangkan. Untuk konfirmasi sensitifitas desain modifikasi sensor yang akan dibuat, ekperimen dilakukan dengan dua tahap. Pertama, sensitifitas desain konvensional diklarifikasi. Pada konfigurasi ini, pick up coil sebagai bahan aktif sensor dan kumparan sebagai koil eksitasi dibuat masing-masing terpisah satu dengan lainnya. Kedua, modifikasi sensor dalam bentuk konfigurasi terintegrasi dikembangkan. Pada desain ini, baik sensor aktif flux gate dan koil eksitasi dibuat pada satu inti magnetik. Ferrite dan inti besi lunak standar digunakan pada eksperimen ini. Untuk perhatian bahwa frekuensi $50 \mathrm{~Hz}$ digunakan pada keseluruhan rangkaian eksperimen. Hasil menunjukkan bahwa sensitifitas dari sensor konfigurasi terintegrasi jauh lebih besar daripada konfigurasi konvensional. Kemudian, konsumsi daya dari flux gate sensor terintegrasi juga lebih rendah daripada sensor konfigurasi konvensional. Akhirnya, jangkauan pengukuran dari sensor konfigurasi terintegrasi dapat direalisasikan lebih kecil daripada 20 pT yang berpotensi bisa mengindera suatu perubahan medan manget lokal alami.

Kata Kunci-double pick up coil, kurva histeresis, medan magnet

\section{INTRODUCTION}

$\mathrm{D}$ evelopment of a narrow-wide range magnetic sensor to detect a changed natural magnetic field source become a great attention researchers for one decade later. In related to the topic, there are several physical methods available to sense the magnetic field such as Hall Effect method, magneto-resistance method, SQUID and induction method via flux gate sensor. However, flux gate sensor is one interesting method due to high resolution, high sensitivity [1] and easy to design for many application. Other, the sensitivity sensor can be increase by inserting magnetic core material i.e. permalloy and CoP [2-3]. In order to lowering noise, flux gate sensor can be adjusted to obtain minimum resonance ripple from uncertain noise source [4-7].

Advantage properties wrote the above i.e. high sensitivity and easy design is keys technology for various applications for example to detect anomalous magnetic field due to disaster such as earth quarks, volcano or land-slide, will stimulate the different of local magnetic field [8]. Here the required-resolution sensor must be less then $60 \mu \mathrm{T}$ i.e. magnitude-order of magnetic field generated from defines volume of the earth rock. Generally, there are two methods to enhance sensitivity flux-gate sensor. First, raise operating frequency until megahertz using core magnetic owing high permeability.

Budi Purnama, Suharyana, and Artono Dwijo Sutomo are with Department of Physics, Faculty of Mathematical \& Natural Sciences, Universitas Sebelas Maret, Surakarta, 57126, Indonesia. E-mail: bpurnama@mipa.uns.ac.id.
The method also increases a measurement noise. Second, scale down sensor size to two dimensions (2D) on an integrated single chip. A later method is necessity photo lithography technique which complicated enough and expensive. Some paper also report scale down to 2D on PCB (Printed Circuit Board).

Following paper systematically discuss about magnetic sensor based on a simple double pick up coil flux gate sensor. Output signal of sensor element enter to conditioning circuit and finally display on digital oscilloscope Yokogawa. The double pick up coil use to ensure that signal output only generate from field. Experiments focus on enhance of magnetic sensor related to number turn and diameter coil which carried out in three steps i.e. fundamental design, linear design and modify of geometrical design. IC op 07 used both differential and non-inverting operating amplifier of conditioning circuit. Characteristic hysteresis curves realize in $10-\mu \mathrm{T}$ range order of magnetic field is a desired physical parameter in this experiment.

\section{METHOD}

Several steps of procedure had carried out in the following experiment. Firstly, flux gate sensors produce. Flux gate sensor consist double pick up coil with same number of turn coil but different direction coil each and other. Here, two type's sensors fabricate i.e. fundamental and integrated design. At fundamental design, activeelement separately fabricate with excitations coil. In contrast for integrated design, excitation and flux gate sensor incorporated on ferrite core realized one system sensor. 
Next step is conditioning circuit realization. IC op 07 used both in integrator and non-inverting amplifier circuit. Figure 1 show circuit electronic which used in the experiment. Conventional configuration consist excitation coil $(\mathrm{Np})$ and pick up coil separate each and other. Contrast for integrated configuration, $\mathrm{Np}$ and Ns combined in a single core sensor. In order to reduce noise, capacitor of $100 \mathrm{nF}$ is used connecting to power supply op amp circuit and grounding in other side. Finally, characteristic of hysteresis curve is displayed on digital oscilloscope. In this study, hysteresis curve characterization is a focus investigation related to the improved sensitivity sensor by physical parameter or design

\section{RESUlTS AND DisCUSSION}

Figure 2 illustrated magnetic response of magneticfield response appeared as hysteresis curve. As shown at the figure, $V_{\text {output }}$ linearly increase with the increase of $H$ and $V_{\text {output }}$ become constant after $H=225 \mu \mathrm{T}$. Similar response indicates at negative field direction as shown at the picture. This curve illustrates a regime operation of the sensor.

Figure 3 depict a typically changed of hysteresis curve due to different number coil. Clearly, the curve modify with the increased of number turn coil. When sensitivity associated to slope of the hysteresis curve so the changed of $\mathrm{N}$ will adjust the sensitivity of sensor. Other wide of hysteresis curve also modify. As shown Figure 3a, for $\mathrm{N}=800$, hysteresis curve realize a linear curve for interval $-310 \mu \mathrm{T}$ to $310 \mu \mathrm{T}$. Contrast for $\mathrm{N}=1200$, hysteresis curve appear broad. In order to confirm critical sensitivity of sensor, various $\mathrm{N}$ is performed as illustrate at Figure 3b. As shown at the figure, sensitivity (slope) increase with the increased of $\mathrm{N}$ and tends constant after $\mathrm{N}=1000$. The result indicated that sensitivity of sensor can not always improve by the increased of $\mathrm{N}$ due to hysteresistic characteristics.

Design of integrated flux gate sensor illustrate at Figure 4. Clearly shown that effectively induce field realize one cycle hysteresis curve much better that conventional one. In previous scheme, bias of field sweeps $-400 \mu \mathrm{T}$ to $400 \mu \mathrm{T}$ form one cycle hysteresis. In contrast for linearly integrated scheme, it only requires field of $\pm 25 \mu \mathrm{T}$ realize one typical hysteresis curve. This result indicate operating regime of the sensor when applied in magnetic sensor system. Narrow regime show high sensitivity due to a large ratio $V_{\text {out }}$ divides $H$. Typically sensitivity of conventional flux gate sensor in this experiment is $150 \mathrm{mV} / \mu \mathrm{T}$. Whereas, for linearly integrated flux gate sensor is about $450 \mathrm{mV} / \mu \mathrm{T}$.

Figure 5 show typical different responses of two dissimilar geometrical configurations. One configuration is flux gate sensor put at one side of excitation coil. Other flux gate sensor set symmetry in the middle of excitation coil. Clearly observe from the figure that symmetry configuration realize hysteresis curve much wider that first case. In interval bias field from $-10 \mu \mathrm{T}$ to $10 \mu \mathrm{T}$, hysteresis curve of symmetry configuration broad of about $7 \mu \mathrm{T}$. In contrast for first case hysteresis form linear and there is no broader observe. The result conduct that optimization of flux gate sensor should be perform at close loop between active sensor and excitation coil. Furthermore, various modify sensor is produce. With in result a typical of key performance for modified flux gate sensor as shown as at Table 1. From the result suggested that the square configuration is the best configuration with range field measurement less than 7 Oe.

\section{CONCLUSION}

Sensitive Magnetic Field Sensor Based on Compensated Double Pick Up Coil have been developed. Experiment carried out in two step i.e. effectively confirmed conventional configuration of flux gate sensor and investigated optimum geometrical configuration. Experimental results show sensitivity realize different between conventional and integrated configuration. Flux gate sensor realized in close loop between active sensor and excitation on singe core should be performed. Finally, integrated configuration can realized less than 20 $\mu \mathrm{T}$ and potential may sense a change of natural local magnetic field.

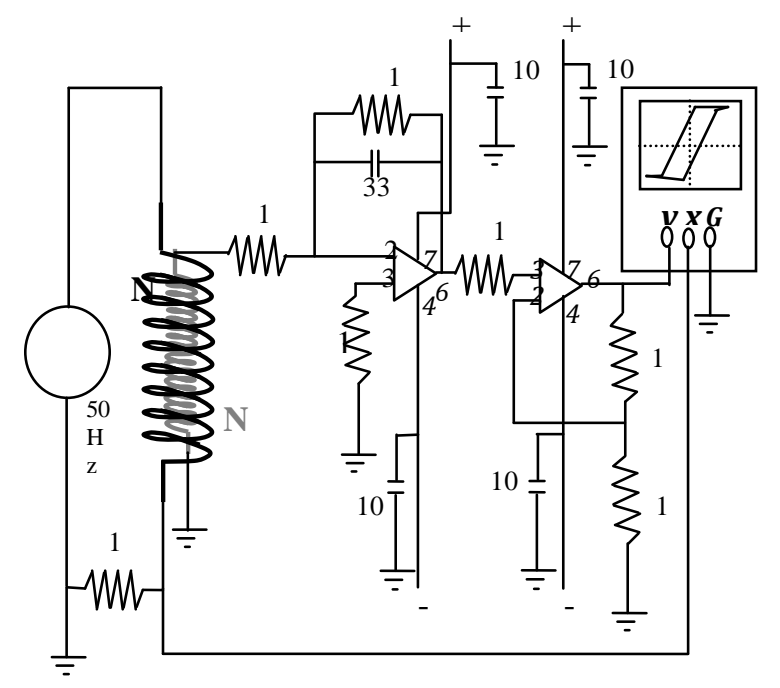

Figure 1. A fully schematic hysteresis loop circuit used

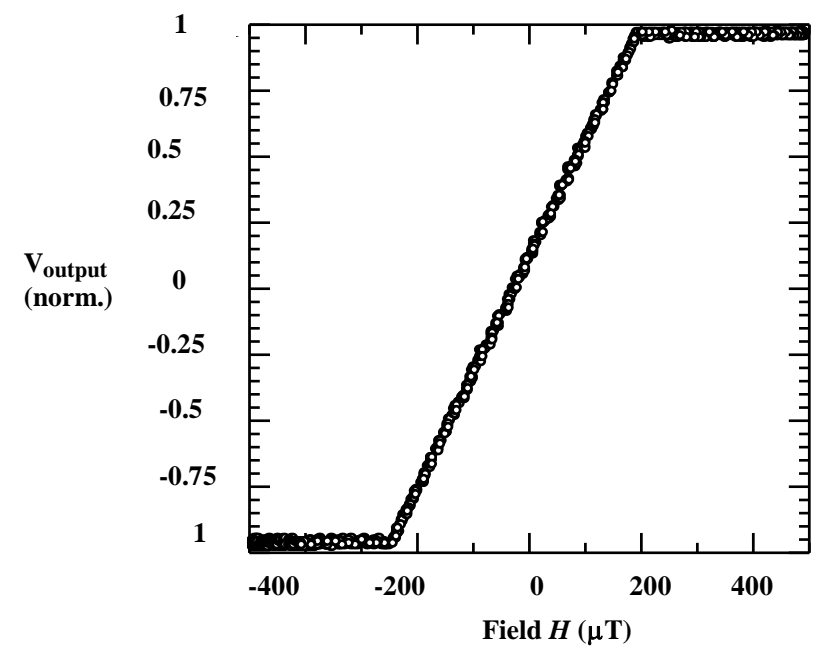

Figure 2. Magnetic-field response of fluxgate sensor appeared as hysteresis curve 


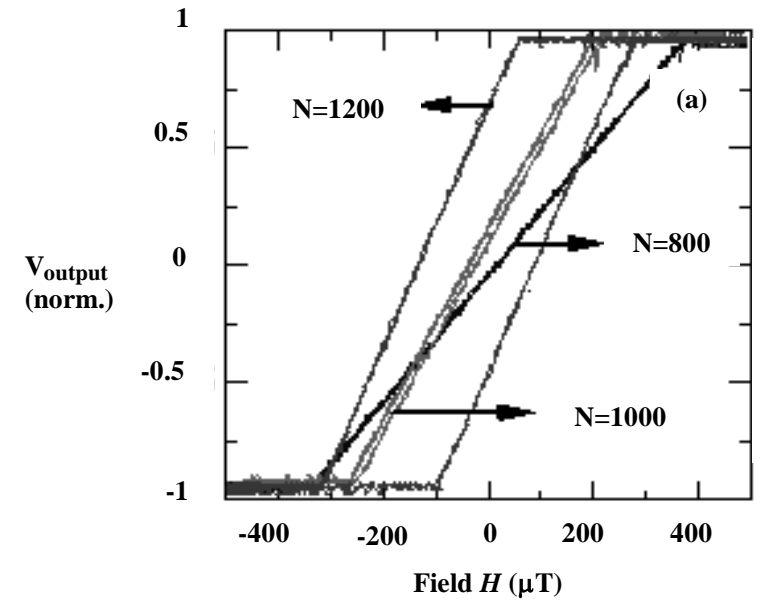

(a)

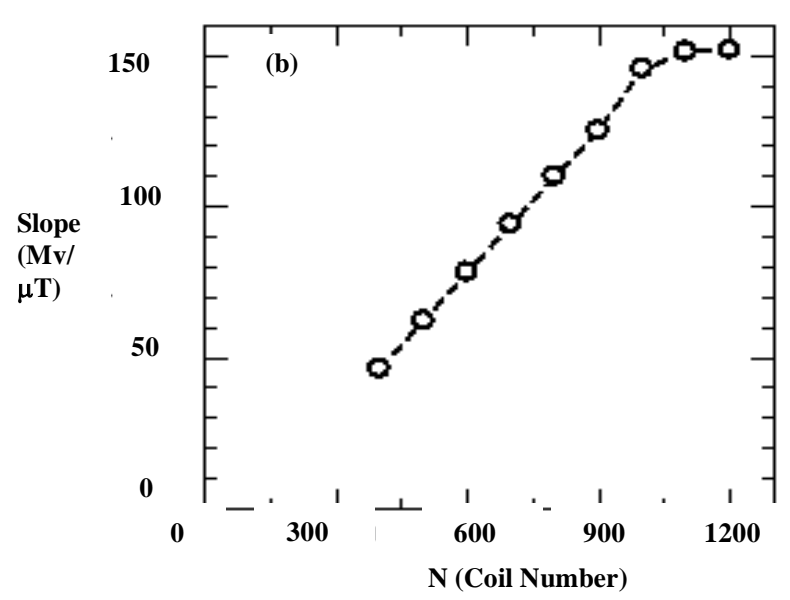

(b)

Figure 3. (a) A typically changed of hysteresis curve for different $\mathrm{N}$, (b) slope as a function as number coil $\mathrm{N}$
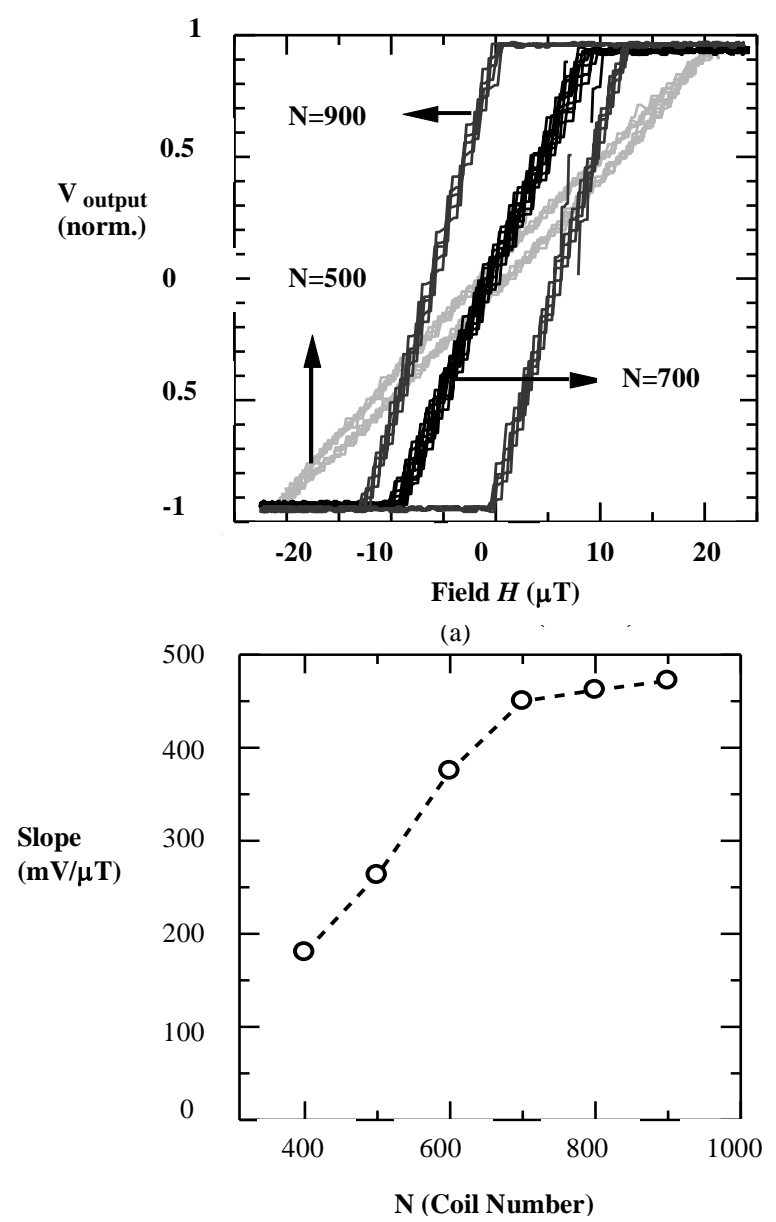

(b)

Figure 4. (a) A typical flux gate sensor performance and (b) the sensitivity as a function of coil number $(\mathrm{N})$ in linearly configuration.
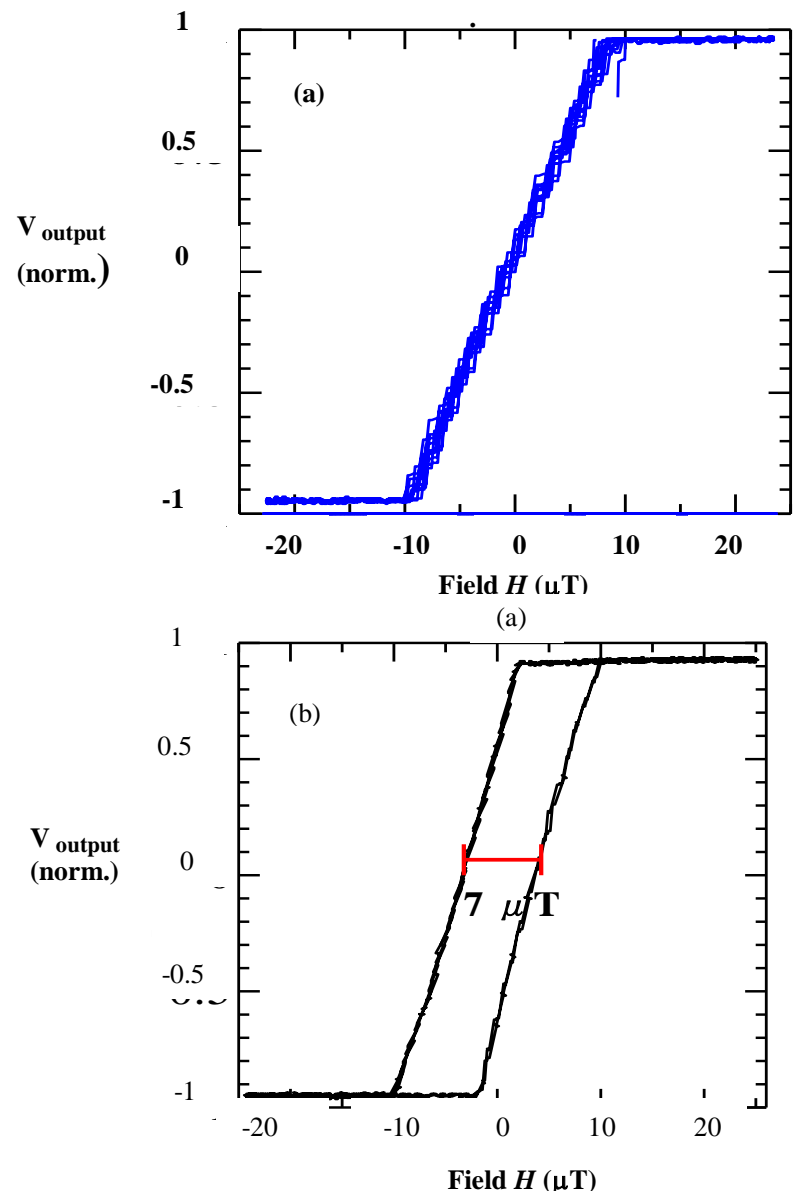

(b)

Figure 5 a typical different response of hysteresis characteristic curve for magnetic sensor in linear single core with 2 modify double pick up coil (a) linear enrich length dan (b) symmetry linear with $\mathrm{N}=700$. 
TABLE 1

Keys Performance OF FluX Gate Sensor Measured FOR Frequency 50 HZ N=700, $\varnothing$ WiRE=0,1 MM Sensitivity $(\mathrm{mV} / \mu \mathrm{T}) \quad$ Range fied $( \pm \mu \mathrm{T}) \quad$ power consumme $(\mathrm{mW})$

\begin{tabular}{lccc}
\hline Konventional & $\sim 150$ & $200 \mathrm{~s} / \mathrm{d} 1000$ & $\leq 50 \mathrm{~mW}$ \\
$\begin{array}{l}\text { Integated design } \\
\text { Linear }\end{array}$ & $\leq 400$ & $\geq 20$ & $\geq 15$ \\
Linear & $\leq 400$ & $\geq 10$ & $\geq 15$ \\
simmetry & & & \\
rod & $\leq 500$ & $\geq 12,5$ & $\geq 10$ \\
Race track & $\leq 500$ & $\geq 10$ & $\geq 10$ \\
square & $\leq 500$ & $\geq 7$ & $\geq 10$ \\
\hline
\end{tabular}

\section{REFERENCES}

[1] P. Ripka, Advance in Fluxgate Sensors, Sensors and Actuators A, no. 106 p.8-14. 2003.

[2] L. Perez, C. Aroca, P. Sanches, E. Lopez and M.C. Sanches, Planar Fluxgate Sensor With An Electrodeposited Amourphous Core, Sensors and Actuator A. no.109. p. 208-211. 2004.

[3] T. O’Donnell, A.Tipek, A.Connell, P. McCloskey, and S. C. O’Mathuna. Planar Fluxgate Current Sensor Integrated In Printed Circuit Board, Sensors and Actuator A no. 129. p. 20-24. 2006.

[4] W.-Y. Choi, K.-Y. Park, B.-C. Koh, M.-S. Kang, K.-W. Na and S.-O. Choi. "A Fabricating Method For A Fluxgate Sensor Inte- grated In Printed Circuit Board", U.S. Paten 0172480, A1, 2005.

[5] M. Janosek and P. Ripka, Current-Output of PCB Fluxgates, Sensor Letters, vol. 7. p. 1-4. 2009.

[6] J. Kubik, J. Vcelak, T.O'Donnell and P.Mc.Closkey. Triaxial Fluxgate Sensor With Electroplated Core, Sensors and Actuators A 152. p. 139-145. 2009.

[7] P. Ripka, X.P.Li and J. Pan, Multiwire Core Fluxgate, Sensors and Actuators A, 156. p. 265-268. 2009.

[8] Basschirotto, A. Dallago, E. Ferri, M. Malcovati, P. Rossini, A. and G. Venchi, "A 2D Micro-Fluxgate Earth Magnetic Field Measurement Systems With Fully Automated Acquisition Setup", Measurement Vol. 43. p. 46-53. 2010. 